\title{
THE DECAY OF NANTO STONE IN AN OUTDOOR-SHELTERED ENVIRONMENT IN THE CLOISTER OF SAINT ANTHONY BASILICA IN PADOVA
}

\author{
Fassina, V..$^{\left({ }^{*}\right)}$, Benchiarin, $S .^{2} \&$ Molin, G. ${ }^{2}$ \\ ${ }^{1}$ Former Superintendence to Fine Arts of Veneto, Veneto, Italy \\ ${ }^{2}$ Former dept. of Cultural Property, Univ. of Padova, Padova, Italy \\ E-mail:vasco.fassina@gmail.com
}

\begin{abstract}
The present work aims to define the type and extent of deterioration in the funerary monument to Giovanni Calfurnio (1443-1503), a valuable Renaissance artwork of Antonio Minello. The monument is made of Nanto stone, a soft yellow-brown stone, often used locally for its aesthetic qualities and easy working. In order to plan urgent restoration work, characterisation of the stone and decay products, by means of classic mineralogic-petrographic and chemical methods was carried out. Since its realization until 1871 it stayed inside a church, and successively it was moved to the Novitiates' Cloister of St. Anthony`s Basilica in Padova where, according to detailed photographic documentation, collected since 1900 up to today, stone decay was considerably increased over the past few decades. Physical parameters such as relative humidity, temperature, wind as well as sulphur dioxide pollution are mainly responsible of the rapid decay observed in the last four decades of the last century.
\end{abstract}

Keywords: Stone decay, Black crusts, Atmospheric pollutants, Carbonaceous particles, Gypsum crystals

\section{Introduction}

The funerary monument to Giovanni Calfurnio (1443-1503) was executed at the beginning of the $16^{\text {th }}$ century. It was conserved until 1871 inside a church and later on it was moved to the Novitiates' Cloister of St. Anthony`s Basilica in a position protected from direct water runoff. The monument is made of Nanto stone, a yellow-brown, marly-arenaceous limestone of middle Eocene age, outcropping near Vicenza (Veneto, North-East of Italy) and quarried along the slopes of southwestern sector of the Berici Hills. This stone, often used locally for its aesthetic qualities and easy working, when exposed to an urban environment, is subjected to severe decay processes [1,2]. In order to plan the urgent restoration work the stone characterisation and the identification of decay products were carried out using the classic mineralogic-petrographic and chemical methods. At the same time a petrographic investigation was carried out on actual Nanto stone quarries to ascertain the monument stone provenance and to investigate the present availability of the lithotype for possible substitutions or integrated purposes of heavily decayed areas and some missing parts of the carved surfaces. The comparison of the photographic documentation collected during the last century has allowed to make a preliminary visual assessment. In fig. (1-a,b) the surface showed the same feature, while in fig. (1-c,d) some decayed parts appeared on the surface and these can be correlated 
to the increasing concentrations of sulphur atmospheric pollutant as it was exhaustive demonstrated in the surveys carried
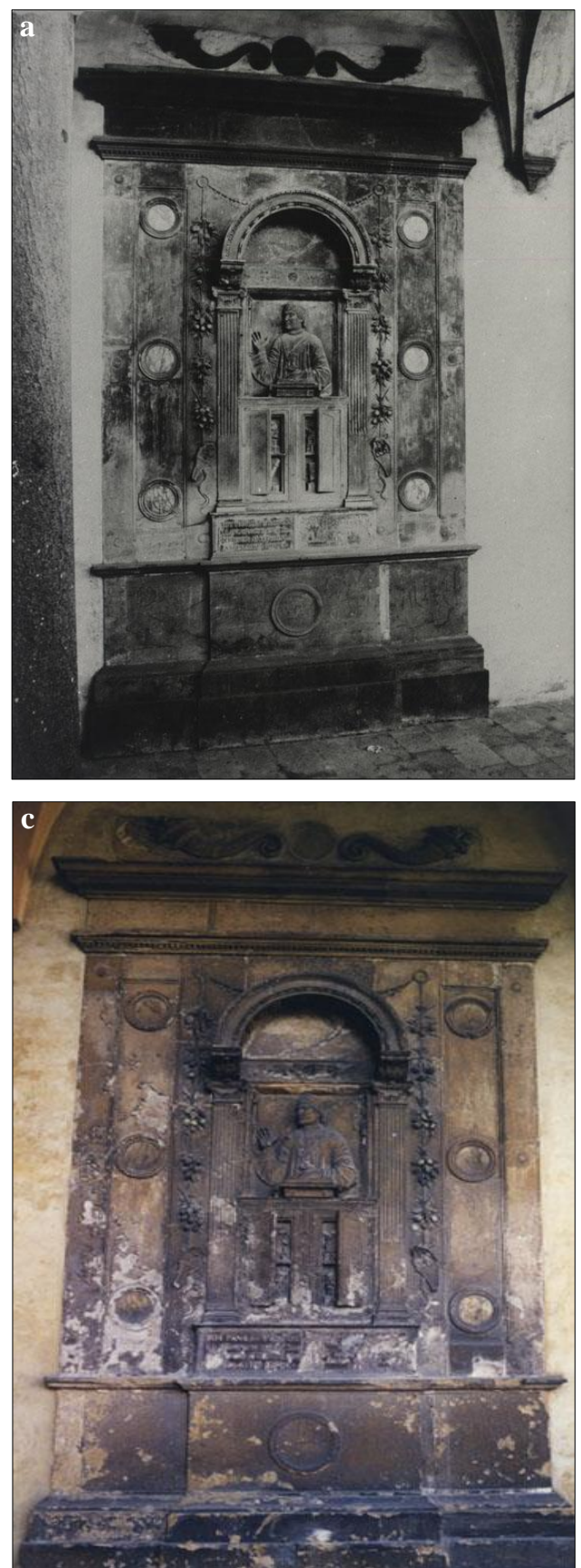

out on Venetian monuments by many authors [3-14].
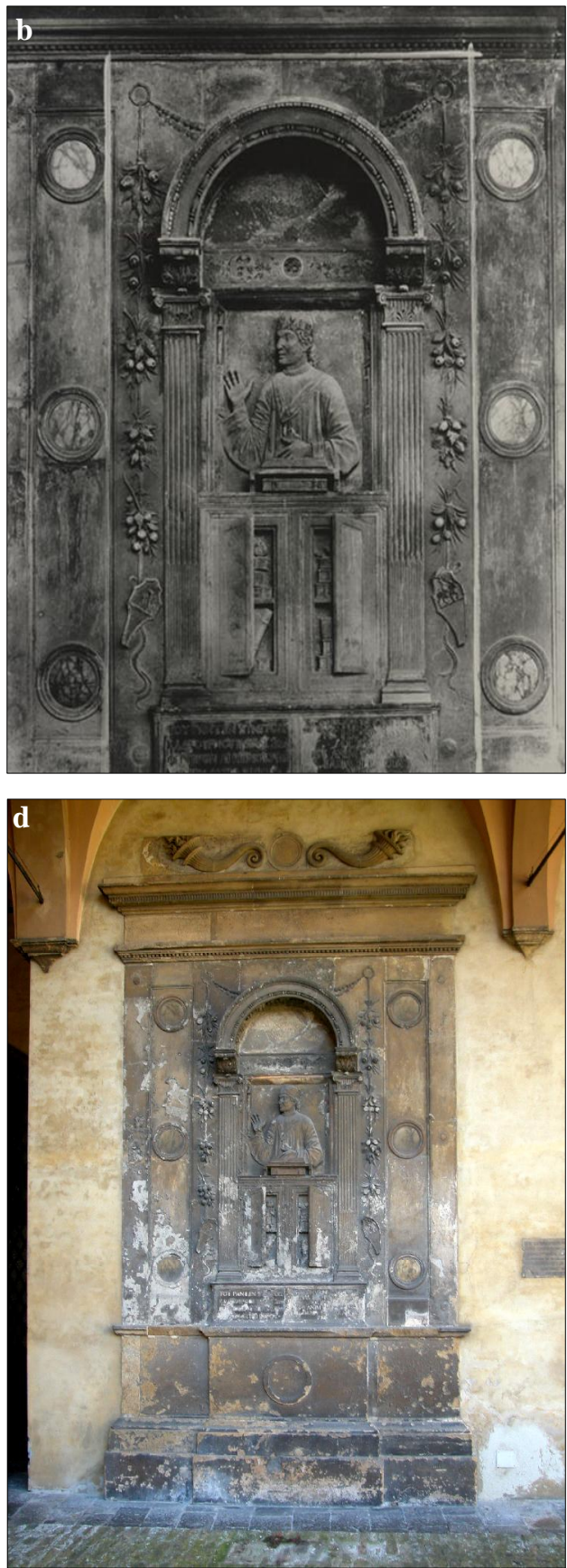

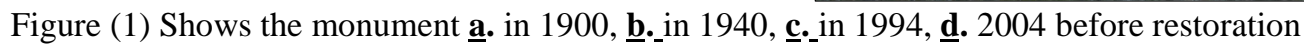

\section{The Outdoor-Sheltered Atmospheric Environment of the Monument}

St. Anthony`s Basilica is located in the centre of Padova, a city that have suffered a rapid post-war industrialization

\subsection{Climatic conditions}

In winter, especially at times of atmospheric stability and limited windy, a situation of thermal inversion prevails, with the accumulation of cold air at the ground. and subject to particular environmental condition, caused by its geographic position in the Veneto lowland.

This favours the formation of fogs and accumulation of the pollutants, enhancing the fog role for stone deterioration. The small diameters of water droplets of fog 
associated with their longer residence time in the atmosphere, allow effective reaction with gaseous pollutants and formation of acidic compounds that interact with the stones [15]. Other thermo-hygrometric factors affecting monument weathering

\subsection{Microclimate}

The monument, located in the West wall of the Cloister with the surface oriented to East is sheltered from rainwater but is exposed to spraying of rain, fog deposition, and to air turbulence associated with frequent condensation-evaporation cycles as well as the water rising from

\subsection{Air pollution}

Various studies have stressed a strict relationship between pollutants and damages to the historical-artistic works [10, 16]. An alarming worsening in the quality of the air in Padova has taken place in recent decades, fig. (2). On an annual basis, vehicles constitute the main source of pollutants like sulphur and nitrogen oxides, organic volatile compounds (VOC), including benzene, carbon monoxide, particulate matter and carbon dioxide. Values in the air of $\mathrm{SO}_{2}$ and particulate matter, grew steadily until the 1980 s, reaching peak levels of $70 \mu \mathrm{g} / \mathrm{m}^{3}$ and $120 \mu \mathrm{g} / \mathrm{m}^{3}$ respectively. These high values were caused by the combustion of large quantities of mineral oils and, to a lesser extent, of coal. In winter periods, when the contribution of domestic heating is added to the normal source of combustion, the most serious situations occurred. However, following the increasing diffusion of methane for domestic heating purposes, the pollution contribution of the sulphur oxides is notably decreased in the years like to the concentration of carbon monoxide, are: relative humidity cycles (winter: 50 $80 \%$, summer: 47-72\%), freeze-thaw cycles $\left(33 \mathrm{yr}^{-1}\right)$ and marked annual temperature variations (winter: $0-9{ }^{\circ} \mathrm{C}$, summer: $\left.15-24{ }^{\circ} \mathrm{C}\right)$.

the ground-floor by capillarity. The wind coming from North and North-East favours evaporation processes which are more enhanced on the left side of the artwork, probably due to stronger ventilation of the corner.

probably due to the use of the catalytic silencers. The concentration of ozone increases during the warm and sunny periods of the year. The particulate matter reaches high values and is essentially due to the industrial activities and the vehicular traffic. As regards the traffic emissions, they are above all the diesel vehicles to contribute; other meaningful sources of dust are caused by to the wear of brakes, rubbers, and road asphalt. There are also present in atmosphere, in form of airborne particulate, heavy metals and lead. All these pollutants are potential sources of deleterious wet and dry deposition processes [17]. High levels of vehicle emissions are reflected in the blackening of many buildings in the city centre, where traffic reaches high densities every day. These emissions, combined with slow wind and high relative humidity, cause stagnation of pollutants and produce a blanket of smog. This smog contains high concentrations of carbonaceous particles and small quantities of heavy metals which may catalyse a sulphation reaction.

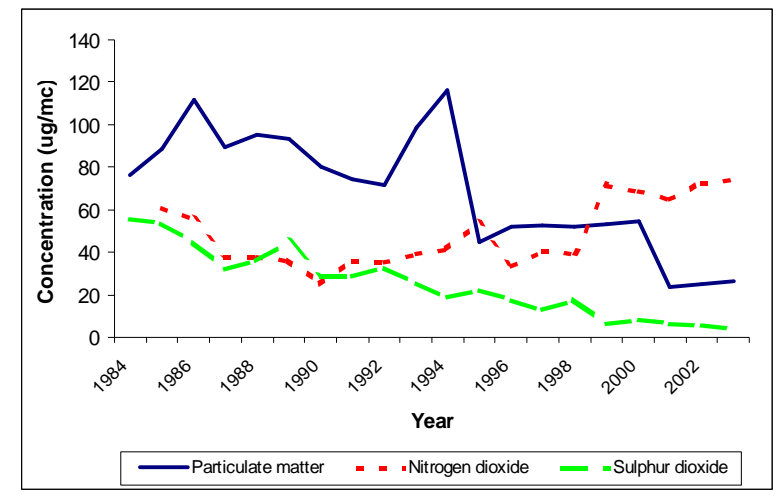

Figure (2) Shows concentrations trend of sulphur, nitrogen dioxide and particulate matter in the urban centre of Padova from 1984 to 2003 


\section{Sampling and Analytical Methods}

Extensive sampling of the monument was performed following the European standard EN 16085 [18]. After a careful macroscopic observation, several microflake samples, tab. (1), representative of the two most common macroscopic stone varieties used in the decoration of the monument have been taken. Surface samples were collected from those areas of the bas-relief which showed severe symptoms of stone deterioration: damaged layers were scraped off, fragments of black crusts and stone were removed while salt efflorescence were sampled on the outer surfaces of the slabs of the ornamental stone; care was taken to ensure that the samples were representative of the whole monument, fig. (3). The samples were dried, ground and stored in sealed containers until characterization by a combination of physical-chemical analytical techniques. Monument stone and decay products have been qualitative and quantitative characterized by mineralogic-petrographic and physico-chemical diagnostic investingation, Optical microscope (OM) and scanning electron microscope equipped with a dispersive energy microanalyser (SEM-EDS) were used for thin section observation. The characterization of bulk samples and the insoluble residue was performed by X-ray diffraction (XRD) with a Philips X'Pert Pro with $\theta-\theta$ geometry, employing $\mathrm{CuK} \alpha(1,54 \AA) \mathrm{rad}-$ iation filtered by nickel at the following operative condition: $40 \mathrm{KV} / 40 \mathrm{~mA}$, while $\mathrm{X}$-ray fluorescence (XRF) with WDS Philips PW2400 sequential spectrometry was used for the elemental composition analysis. Sulphur, carbon, nitrogen and hydrogen were measured by EA 1110 CHNS analyzer, while organic carbon was obtained by subtraction of the total carbon performed by CHNS analysis and the inorganic carbon performed with thermal analysis. Differential thermal analysis (DTA) and thermo gravimetric analysis (TGA), with a heating rate of $10{ }^{\circ} \mathrm{C} \mathrm{min}^{-1}$ were use for the determination of gypsum and carbonates. Anion concentrations such as, sulphates, oxalates, nitrates and chlorides, were measured by ion chromategraphy (IC) using a Dionex DX100 equipped with AS4A-SC column. The morphological characteristics of the black crusts have been observed by examining 3D samples using secondary electrons of scanning electron microscopy (SEM). The presence of organic compounds was determined by infrared spectroscopy (FT-IR). The petrographic classification adopted is that proposed by Dunham [19] with modifycation by Embry \& Klovan [20].

Table (1) Description of samples and type of analyses performed.

\begin{tabular}{lll}
\hline Sample & \multicolumn{1}{c}{ Description of the sample } & \multicolumn{1}{c}{ Type of analysis } \\
\hline MFC1 & Yellowish-brown rock fragments & OM, XRD, XRF, DTA, TGA, CHNS \\
MFC2 & Yellowish-brown rock fragments with superficial black scabs & OM, XRD, XRF, SEM, DTA, TGA, CHNS \\
MFC3 & Greyish-black scab & OM, XRD, SEM, XRF, \\
MFC4 & Yellowish-brown rock fragments & OM, XRD, XRF, DTA, TGA, CHNS \\
MFC5 & Yellow rock fragment & OM, XRD, SEM \\
MFC6 & Greyish-white patina & XRD \\
MFC7 & Greyish-black scab & OM, XRD, SEM \\
MFC8 & Yellow fragments & XRD \\
MFC9 & Black scab & OM, XRD, SEM \\
MFC10 & Superficial black patina & XRD \\
MFC11 & Grey rock fragments & OM, XRD, SEM,XRF, DTA, TGA, CHNS \\
MFC12 & Grey rock fragments & OM, XRD, SEM, DTA, TGA, CHNS \\
MFC13 & Greyish-Black scab & OM, XRD, SEM, XRF, DTA, TGA,CHNS \\
MFC14 & Greyish-Black scab & OM, XRD, SEM, XRF, DTA, TGA,CHNS \\
MFC15 & Rock fragment & SEM \\
MFC16 & Red pigmentation & OM, SEM \\
MFC17 & Black pigmentation & OM, SEM \\
MFC18 & Blackish-grey fragments & OM, SEM \\
MFC19 & Rock dust & IC \\
\hline
\end{tabular}




\begin{tabular}{lll}
\hline MFC20 & Golden-yellow scab & IC \\
MFC21 & Bituminous black scab & OM, SEM \\
MFC22 & Acetone tampon & FT-IR \\
MFC23 & Rock dust & IC \\
MFC24 & Black scabs & XRD, XRF, DTA, TGA, CHNS \\
MFC25 & Salt efflorescence & XRD, SEM \\
MFC26 & Salt efflorescence & XRD \\
MFC27 & White patina & XRD \\
C1 & Yellowish-brown rock fragments & OM, XRF \\
\hline
\end{tabular}

$\boldsymbol{O M}=$ Optical Microscope; $\boldsymbol{X} \boldsymbol{R} \boldsymbol{D}=\mathrm{X}$ Ray Diffraction; $\boldsymbol{X} \boldsymbol{R} \boldsymbol{F}=\mathrm{X}$ Ray Fluorescence; $\boldsymbol{D T A}=$ Differential Thermal Analysis; $\boldsymbol{T} \boldsymbol{G A}=$ Thermo Gravimetric Analysis; $\boldsymbol{C H N S}=$ Carbon Hydrogen Nitrogen Sulphur $\boldsymbol{S E M}=$ Scanning Electron Microscopy; $\boldsymbol{I C}=$ Ion Chromatography; $\boldsymbol{F T}-\boldsymbol{I} \boldsymbol{R}=$ Fourier Transmission Infrared Spectroscopy.

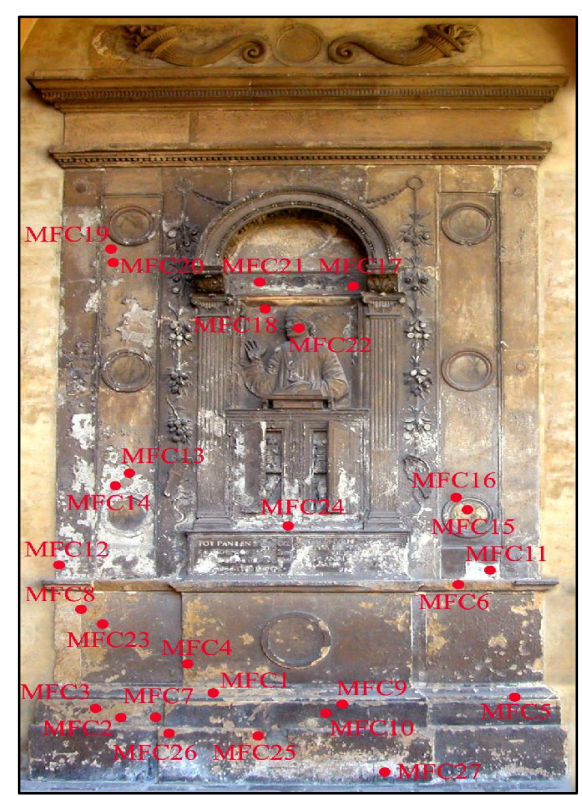

Figure (3) Shows sampling location

\section{Results}

The sections below report the results of mineralogical, petrographic and chemical analysis carried out on the yellowishbrown and greyish lithotypes used in the monument. The samples, although are characterized by different chromatic feature, can be petrographically classified as grainstone/packstone, even if some samples show a laminar structure so that are classified as bind stone with laminae constituted by grain stone; the matrix is discrete, porosity is high and cementation is fair. The texture is clastic-organogenic, with grain support. The skeleton is mainly due to Benthic and Planktonic Foraminifera, plates and spines of Echinoderms, Red Algae and rare few microns sized skeletal debris. The skeletal grains, with sutured grain boundaries, are cemented by sparite and micro-sparite of carbonate crystals (calcite and dolomite), and rare goethite. More evident is the clear calcite syntaxial ove- rgrowth cement on plates and spines of Echinoderms. The mesopores are cemented by drusy calcite. In thin section it was observed clear euhedral dolomite rhombuses casually disseminated in the rock. The siliciclastic fraction is very low in the stone $(<1 \%$ by optical microscope; silica is attested on $4-5.5 \%$ for all samples while aluminium on $1.4-2.7 \%$ by XRF), and made up of a few isolated grains of biotite, glauconite, chlorite, phosphates, pyrite, quartz, feldspars and clay minerals (mainly smectite), as shown by thin section and XRD analysis. The samples are mainly composed of calcite (by XRD) confirmed also by XRF that shows average values of $42 \%$ in terms of $\mathrm{CaO}$, although goethite, dolomite and ankerite are also abundant, fig. (4). The XRD of the insoluble residue (15\%) shows clay minerals (smectite), quartz, chlorite and K-feldspar. 


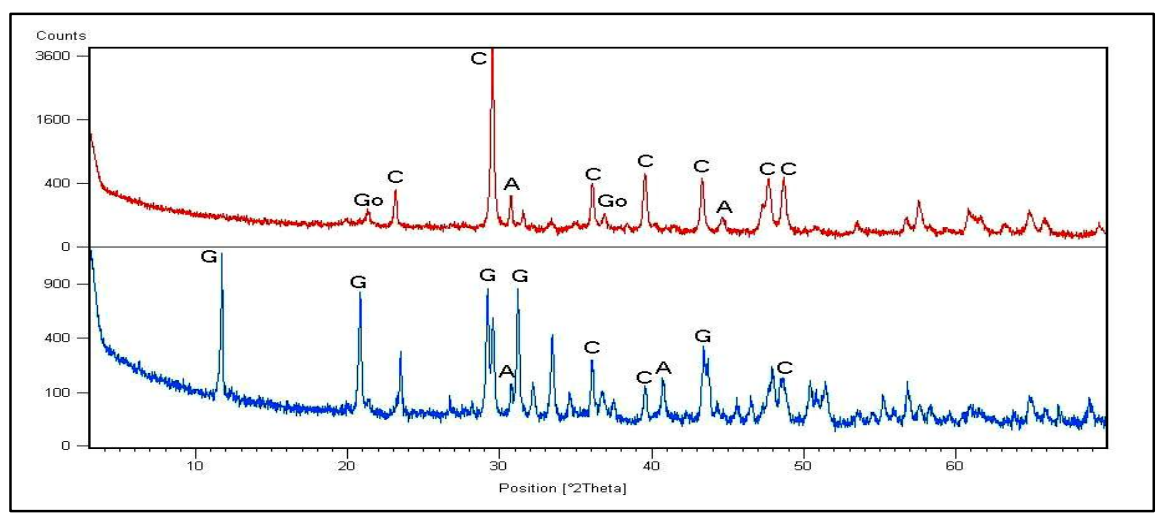

Figure (4) Shows X-ray diffractogram of rock sample MFC1 and a sample of damaged layer MFC5. $\boldsymbol{G}=$ gypsum; $\boldsymbol{C}=$ calcite $; \boldsymbol{G o}=$ goethite; $\boldsymbol{A}=$ ankerite.

Thermal analyses (TGA+DTA), tab. (2) discriminated the presence of carbonates, with values between $55 \%$ and $74 \%$ (average 66\%). TGA+DTA analysis also showed high quantities of gypsum, due to decay processes, and minor amounts of various iron and clay minerals, characterized by loss of weight at low temperatures. The grainstone/ packstone lithotype shows three compositional varieties: i) the first variety is essentially composed by Echinoderms, Red Algae and Foraminifera with prevalence of the benthic on the planktonic, fig. (5-a,b) (samples MFC 1,2,3,5,7,9). ii) The second variety is different from the previous one for the small quantity of Algae and for the presence of intraclasts. The cementation results more evident than in the other ones (sample MFC4). iii) the third variety is characterised by the predominance of Red Algae on the other bioclasts, lesser quantity of Echinoderms and for the prevalence of the planktonic with respect to the benthic Foraminifera. A bijection exists between Red Algae and planktonic Foraminifera, fig. (5-c) (samples MFC 11, 12, 13, 14).

Table (2) Gypsum and carbonate concentrations measured by TGA expressed as percentages.

\begin{tabular}{lccccccc}
\hline \multicolumn{1}{c}{ Sample } & MFC1 & MFC2 & MFC4 & MFC12 & MFC13 & MFC24 \\
\hline Carbonates & 73 & 64 & 64 & 74 & 56 & 61 \\
Gypsum & - & 12 & 13 & 10 & 32 & 26 \\
\hline
\end{tabular}

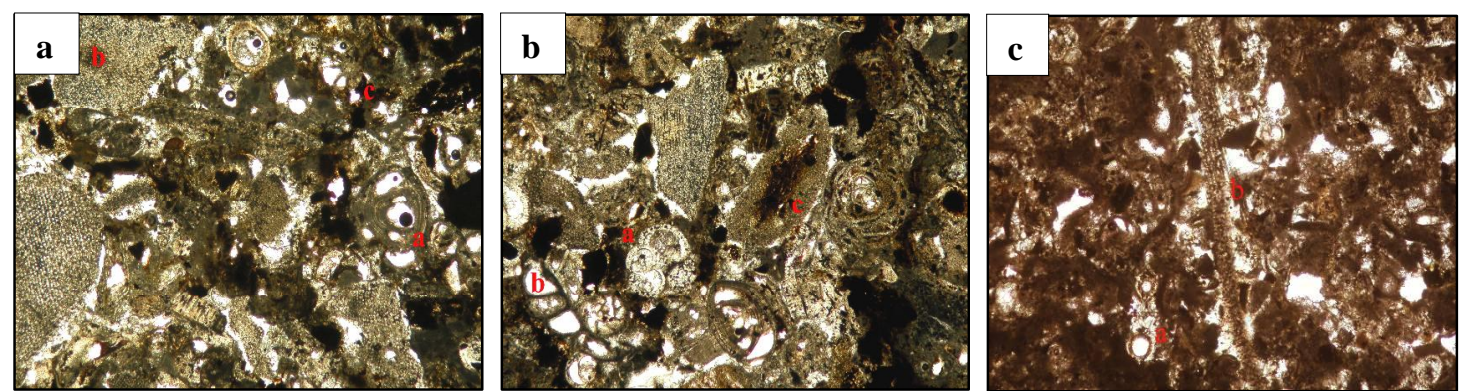

Figure (5) Shows coarse grain stone a. with foraminifera, echinoderms (sometimes of millimetric dimensions), globigerinoides and few micro sized skeletal debris. intragranular carbonate cement (a), diffuse goethite (b). nanto stone. Nicols //, 2.5 x., $\underline{\mathbf{b}}$. with hyaline (a) and porcelaneous (b) calcareous foraminifera. plates of echinoderms (c) with clear calcite syntaxial overgrowth cement. nanto stone. Nicols //, 5x, $\underline{\mathbf{c}}$. fine grain stone with hyaline planktonic foraminifera (a) and occasional millimetric dimensions spines of echinoderms (b). Nanto Stone. Nicols //, 10x.

Brownish-reddish iron oxides hydroxide grains (identified by XRD as goethitelimonite) are significantly more abundant in the yellow-brown ground-mass (that include I and II varieties) than in the grey one (III variety), in agreement with the $\mathrm{Fe}_{2} \mathrm{O}_{3}$ content of the samples, tab. (3) that confirms the different concentration of 
iron oxides among the different varieties. XRF data of the III variety samples underline an increase of $\mathrm{Mg}$ than in the others, in agreement with the greatest content of Red Algae that can contain up to $30 \%$ of $\mathrm{MgCO}_{3}$. The diagenesis, creating situations of different cementation and compaction, has contributed to modify the textural character. Examination of thin sections highlighted the following diagenetic phases: * Isochemical diagenetic phase: in all samples, if present, the early cement is calcitic. * Allochemical diagenetic phase: the dissolution of the early cement is followed by local precipitation of clear euhedral dolomite rhombuses cement scattered in the rock and occasional changes in the chemistry of the local circulating solutions is responsible of the silicization of some bioclasts. Petrographic characterization, composition and percentages of the insoluble residue, and the chemical analyses of the bulk rock, indicate that the monument is made of "Nanto stone". The composition, generally homogeneous in spite of three varieties, indicates a shallow-water deposit, subject to temporary energy and/or chemical changes. The differences, in fact, do not involve a change of facies, but oscillations of the skeletal amount, ascribed to weak fluctuations of morphology, energy and chemical composition in a depositional basin. In this environmental context the laminated structures, like bind stone, could occur. The classification of these samples as bind stone is due to the discontinuity surfaces which are a earlier cyanobacterial structures enhanced by the deterioration. Structural, textural and compositional characteristics suggest that all samples belong to the same lithotype and come from the same quarry.

Table (3) Elemental composition of samples measured by XRF.

\begin{tabular}{|c|c|c|c|c|c|c|c|c|c|}
\hline \multicolumn{10}{|c|}{ Major elements (\%) } \\
\hline Oxide & MFC1 & MFC2 & MFC3 & MFC4 & MFC11 & MFC12 & MFC13 & $M F C 24$ & $C 1$ \\
\hline $\mathrm{SiO}_{2}$ & 5.55 & 5.08 & 3.99 & 5.04 & 4.62 & 4.41 & 3.91 & 5.53 & 4.90 \\
\hline $\mathrm{TiO}_{2}$ & 0.45 & 0.36 & 0.28 & 0.39 & 0.31 & 0.28 & 0.26 & 0.33 & 0.29 \\
\hline $\mathrm{Al}_{2} \mathrm{O}_{3}$ & 2.72 & 2.28 & 1.90 & 2.49 & 1.65 & 1.51 & 1.40 & 1.84 & 1.91 \\
\hline $\mathrm{FeO}$ & 0.24 & 0.24 & 0.27 & 0.24 & 0.21 & 0.24 & 0.20 & 1.93 & 0.63 \\
\hline $\mathrm{Fe}_{2} \mathrm{O}_{3}$ & 5.75 & 4.57 & 3.64 & 5.27 & 2.41 & 1.32 & 1.32 & 0.02 & 2.52 \\
\hline MnO & 0.02 & 0.02 & 0.02 & 0.02 & 0.02 & 0.02 & 0.01 & 0.02 & 0.02 \\
\hline MgO & 1.62 & 1.36 & 1.32 & 1.67 & 2.02 & 1.70 & 1.44 & 1.48 & 0.68 \\
\hline $\mathrm{CaO}$ & 42.10 & 41.09 & 42.71 & 42.27 & 44.34 & 45.79 & 44.19 & 43.38 & 48.11 \\
\hline $\mathrm{Na}_{2} \mathrm{O}$ & 0.32 & 0.29 & 0.27 & 0.34 & 0.20 & 0.19 & 0.10 & 0.10 & 0.01 \\
\hline $\mathbf{K}_{2} \mathrm{O}$ & 0.63 & 0.73 & 0.53 & 0.60 & 0.59 & 0.47 & 0.43 & 0.61 & 0.41 \\
\hline $\mathbf{P}_{2} \mathbf{O}_{5}$ & 0.27 & 0.21 & 0.18 & 0.25 & 0.10 & 0.11 & 0.10 & 0.13 & 0.17 \\
\hline L.O.I. & 39.49 & 37.50 & 36.59 & 39.61 & 39.81 & 40.14 & 36.78 & 36.14 & 39.97 \\
\hline Total & 99.16 & 93.71 & 91.71 & 98.19 & 96.28 & 96.17 & 90.14 & 91.50 & 99.62 \\
\hline \multicolumn{10}{|c|}{ Trace elements (ppm) } \\
\hline $\mathrm{Sc}$ & $<2$ & $<2$ & $<2$ & $<2$ & $<2$ & $<2$ & $<2$ & $<2$ & $<2$ \\
\hline $\mathbf{V}$ & 178 & 133 & 118 & 169 & 57 & 46 & 50 & 62 & 76 \\
\hline $\mathrm{Cr}$ & 120 & 97 & 74 & 110 & 62 & 47 & 44 & 56 & 56 \\
\hline Co & 11 & 9 & 4 & 11 & 12 & 4 & $<2$ & 4 & 3 \\
\hline $\mathbf{N i}$ & 42 & 33 & 27 & 43 & 40 & 10 & 10 & 15 & 24 \\
\hline $\mathbf{C u}$ & 26 & 28 & 24 & 17 & 16 & 16 & 18 & 25 & 12 \\
\hline $\mathbf{Z n}$ & 83 & 60 & 66 & 58 & 33 & 23 & 41 & 84 & 30 \\
\hline $\mathbf{G a}$ & $<3$ & $<3$ & $<3$ & $<3$ & $<3$ & $<3$ & $<3$ & $<3$ & $<3$ \\
\hline $\mathbf{R b}$ & $<2$ & 8 & 2 & $<2$ & 1 & $<2$ & 6 & 15 & $<2$ \\
\hline $\mathbf{S r}$ & 589 & 555 & 539 & 593 & 571 & 547 & 505 & 495 & 424 \\
\hline $\mathbf{Y}$ & 12 & 8 & 8 & 12 & 10 & 10 & 10 & 13 & 8 \\
\hline $\mathbf{Z r}$ & 33 & 15 & 14 & 22 & 17 & 12 & 21 & 39 & 6 \\
\hline $\mathbf{N b}$ & 5 & 3 & 3 & 4 & 8 & 6 & 9 & 17 & $<2$ \\
\hline $\mathbf{B a}$ & 62 & 73 & 88 & 66 & 66 & 60 & 68 & 93 & 64 \\
\hline $\mathbf{L a}$ & 8 & $<10$ & $<10$ & $<10$ & $<10$ & 7 & $<10$ & 10 & $<10$ \\
\hline $\mathrm{Ce}$ & 22 & 18 & 8 & $<10$ & $<10$ & $<10$ & 12 & $<10$ & 10 \\
\hline
\end{tabular}




\begin{tabular}{lccccccccc}
\hline Nd & 12 & 8 & 12 & 16 & $<10$ & 8 & $<10$ & 11 & 8 \\
$\mathbf{P b}$ & 52 & 51 & 61 & 31 & 51 & 55 & 71 & 119 & 25 \\
Th & 28 & 42 & 23 & 32 & $<3$ & 3 & $<3$ & $<3$ & 45 \\
$\mathbf{U}$ & $<1$ & $<1$ & $<1$ & $<1$ & $<1$ & $<1$ & $<1$ & $<1$ & $<1$ \\
\hline
\end{tabular}

\subsection{Quarry material}

The mineralogic-petrographic and chemical analyses of samples coming from a Nanto stone quarry were compared with the ones related to samples coming from the monument to identify the quarry material with the closest properties of the stone used in the monument and at the same time to identify a stone suitable for possible replacement of some parts of the monument. Petrographic analysis shows notable analogy of structural and textural characteristics compared to the monument lithotype, and particularly with the I and II varieties, fig. (6). The meaningful difference consists in the absence in quarry`s samples of dolomitization (confirmed by the decrease of the magnesium value performed by XRF) in comparison to the samples of the monument. It is possible to affirm that both the lithotypes derived from the same stratigraphic interval or from proximity horizons. The detected differences, in fact, do not involve a change of facies, but oscillations of the skeleton contribution, ascribed to weak fluctuations of morphology, energy and chemical composition in depositional basin. The chemical analysis shows in the quarry sample, tab. (3) (MFC1 sample) minor quantities of some trace elements $(\mathrm{V}, \mathrm{Cr}, \mathrm{Co}, \mathrm{Cu}, \mathrm{Pb}$, $\mathrm{Zn}$ ) conversely enriched in the monument by atmospheric pollution, that develops a kinetic action to decay processes as suggested by Amoroso and Fassina [17].

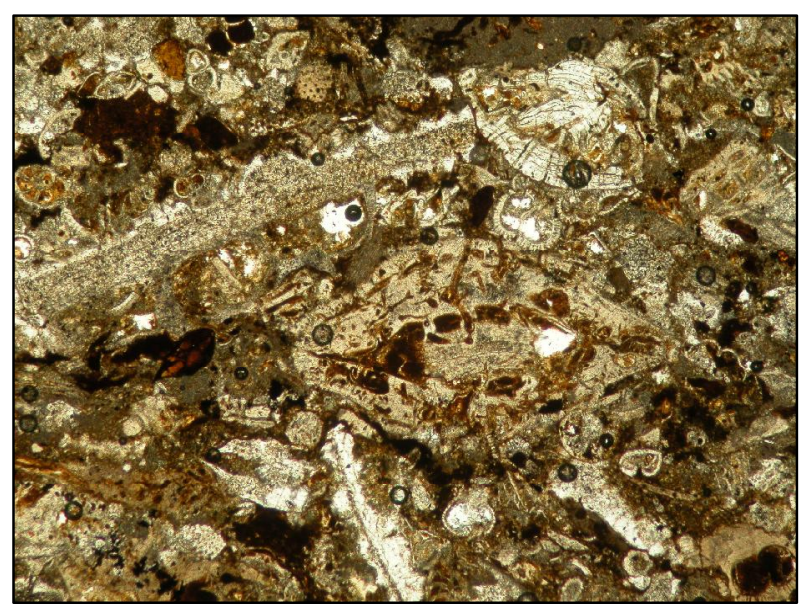

Figure (6) Shows coarse grain stone with hyaline planktonic (a) and benthic (b) calcareous foraminifera and spines of echinoderms (c) syntaxial and intragranular clear calcite cement. Nanto stone. Nicols //, 5x.

\subsection{Soluble salt measurements}

Ion Chromatography (IC) analyses of stone materials taken at different depths from the stone surface by microdrilling technique $[17,21]$ identified sulphates as the most abundant anions, with trends decreasing from the surface inwards. These sulphates, as noted previously, are clearly related to the presence of gypsum. IC analyses show gypsum concentration ranging from $27 \%$ to $36 \%$ on the surface that fall to $1 \%$ in depth, tab.
(4). Quantitative determination of sulphates salts may explain some of the decay phenomena suffered by the monument. SEM`s analyses (BSE images) of cross sections show extensive micro-cracks in the limestone, parallel to the stone/crust interface, completely filled with gypsum. These cracks, of a thickness ranging between 5 to $30 \mu \mathrm{m}$, reach millimetric lengths and may extend to a depth of 5 $\mathrm{mm}$ inside the stone, although it is 
possible that they reach even deeper, fig. (7). These micro-fissures have been observed in the samples classified as bind stone. Although the lamination is certainly enhanced by the deterioration, this seems to have acted on native discontinuity surfaces of probable cyanobacterial structure. Different amounts of nitrates widespread in the stone have been found by IC. Evidence of the migration of water through porous stone is demonstrated by efflorescence at the basement of the monument, composed of salnitre, identified by XRD analysis. Salnitre is probably closely related to capillary rising damp transporting salts coming from decomposing organic materials. CHNS analysis of other samples, tab. (5), taken from the stone surface, showed values of nitrogen lying between $0.15 \%$ and $9.74 \%$, which correspond approximately to a percentage of nitrates lying between $1 \%$ and $43 \%$. Nitrates in the upper part of the monument are probably due to pigeon droppings [17] Chlorides are related to the wind from the Adriatic coast [17], and oxalates to biodegradation products formed by transformations of organic materials applied on the stone surface in the past as part of some form of maintenance treatment. The CHNS determinations allow to justify the lower closing value of the fluorescence analysis (table 1, Total), due partly to the presence of trace elements, but above all to the not negligible content of nitrogen and sulphur not considered in the planning of the same quantitative analysis see table (3). On some parts of the monument the presence of traces of red pigmentation was observed. This pigment, of Si-Al composition, is classified as Red Bole, and was used as a preparation layer for the application of gold leaf. Sample MFC16 contains flakes of gold. Upon floral motif a black pigment wood-based embedded in an organic matrix was found, infrared spectroscopy revealed linseed oil and egg yolk in sample MFC22. The former is probably related to an old attempt to protect the surface, and the latter to the red pigment. The linseed oil probably caused superficial yellowing of the surface.

Table (4) Anion concentrations (\%) of stone material taken at different depths and measured by Ion Chromatography (IC)

\begin{tabular}{lcccc}
\hline \multicolumn{1}{c}{ Sample } & $\mathbf{S O}_{\mathbf{4}}{ }^{2-}$ & $\mathbf{C l}^{-}$ & $\mathbf{N O}_{\mathbf{3}}{ }^{-}$ & Oxalate \\
\hline MFC19a (0-1mm) & 20.10 & - & 0.23 & - \\
MFC19b (1-2mm) & 3.36 & - & 0.35 & - \\
MFC19c (2-3mm) & 3.15 & - & 0.33 & - \\
MFC23a (0-1mm) & 15.44 & 0.39 & 1.70 & - \\
MFC23b (1-2mm) & 1.14 & 0.33 & 1.32 & - \\
MFC23c (2-3mm) & 0.68 & 0.34 & 1.70 & - \\
MFC20a (0mm) & 30.33 & 8.91 & 0.51 & 0.99 \\
MFC20b (1mm) & 26.35 & 0.79 & 0.68 & 0.41 \\
\hline
\end{tabular}

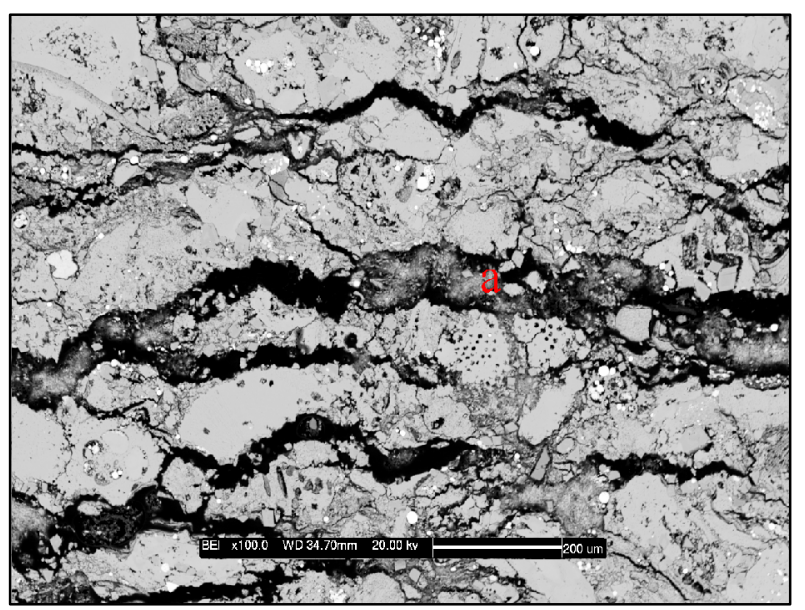

Figure (7) Shows sub-parallel stylolites and micro-cracks of the stone filled with gypsum (a). 
Table (5) Average concentration of sulphur $(\mathrm{S})$, nitrogen $(\mathrm{N})$, total carbon $(\mathrm{C})$, organic carbon $\left(\mathrm{C}_{\mathrm{o}}\right)$ expressed in percentages in black crusts.

\begin{tabular}{lcccc}
\hline Sample & $\mathbf{S}^{\mathbf{a}}$ & $\mathbf{N}^{\mathbf{b}}$ & $\mathbf{C}^{\mathbf{c}}$ & $\mathbf{C}_{\mathbf{0}}{ }^{\mathbf{d}}$ \\
\hline MFC1 & 0.10 & 0.33 & 9.14 & 0.42 \\
MFC2 & 2.30 & 0.41 & 7.90 & 0.25 \\
MFC4 & 0.44 & 0.39 & 9.16 & 1.54 \\
MFC11 & 1.46 & 0.38 & 9.42 & 0.55 \\
MFC12 & 1.32 & 0.30 & 9.38 & 0.46 \\
MFC13 & 4.94 & 0.15 & 7.84 & 1.16 \\
MFC24 & 3.97 & 9.74 & 8.66 & 1.28 \\
\hline
\end{tabular}

${ }^{\mathbf{a}, \mathbf{b}, \mathbf{c}}$ Measured by CHNS, ${ }^{\mathbf{d}}$ Calculated combing TGA and $\mathrm{CHNS}$

\section{Discussion}

Decay processes; petrographic analyses of all surface crusts show gypsum, in both microcrystalline flakes and in acicular crystals. XRD analyses, performed on the fractions obtained by scraping the surface layer of black crust indicate gypsum as predominant phase, fig. (4) due to sulphation processes, according to the characteristics of the atmosphere in contact with the stone surface [17-20, 22-24]. Thermal analyses of decayed stone samples show a significant amount of gypsum, in the range between $8 \%$ and $32 \%$ (average 16\%). Also CHNS analyses indirectly confirm high values of gypsum since sulphur in this type of samples is lying between $0.1 \%$ and $4.94 \%$, tab. (5). SEM analyses (back scattered electrons-BSE images) of decayed crusts cross-sections show a dendritic crust with thickness lying between $30 \mu \mathrm{m}$ and $1 \mathrm{~mm}$. These crusts have two main features: i) irregular aggregates of needle-shaped gypsum crystals (lenticular and minute crystals), sometimes arranged in a fan,

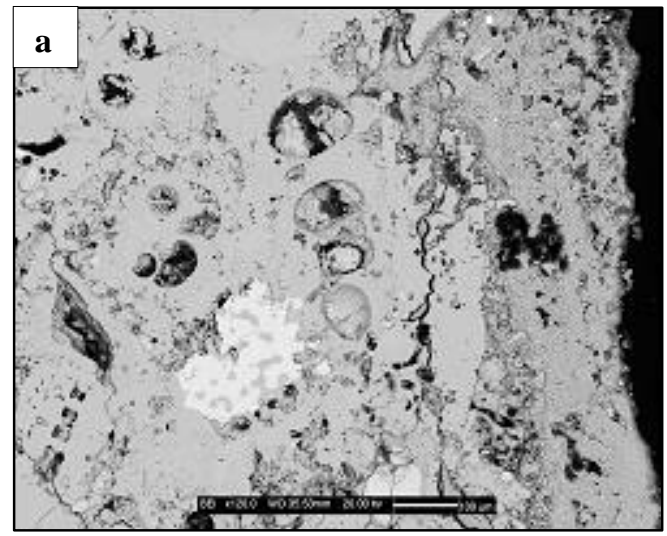

the structure of which is responsible of the high porosity of the crust. The stone/crust interface is transformed into microcrystalline calcite, which shows chemical transformation in progress; ii) embedded in the gypsum crust are iron, titanium and porous carbonaceous particles, with diameters between 10 and $40 \mu \mathrm{m}$ and with concentrations ranging from a few percent to about $30 \%$ by volume. In fig. (8-a,b) (left picture) the substrate (left side of cross-section) is clearly disting-uishable from the damaged area (right side), in which the main component is gypsum, as demonstrated by the $\mathrm{X}$ ray map distribution of sulphur. Three-dimensional images of the black crusts SEM- BSE, show platy crystals of gypsum sets of minute crystals fig. (8-c), carbonaceous, spherical and porous particles, emitted by the combustion of heavy oils [25] fig. (8-d) and smooth spherical particles mainly composed of iron and other metals, derived from the combustion of fossil fuels [2632] fig. (8-e).

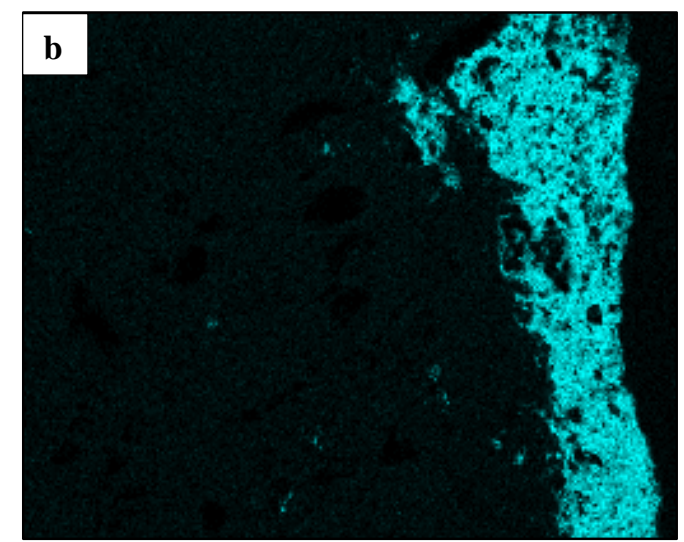



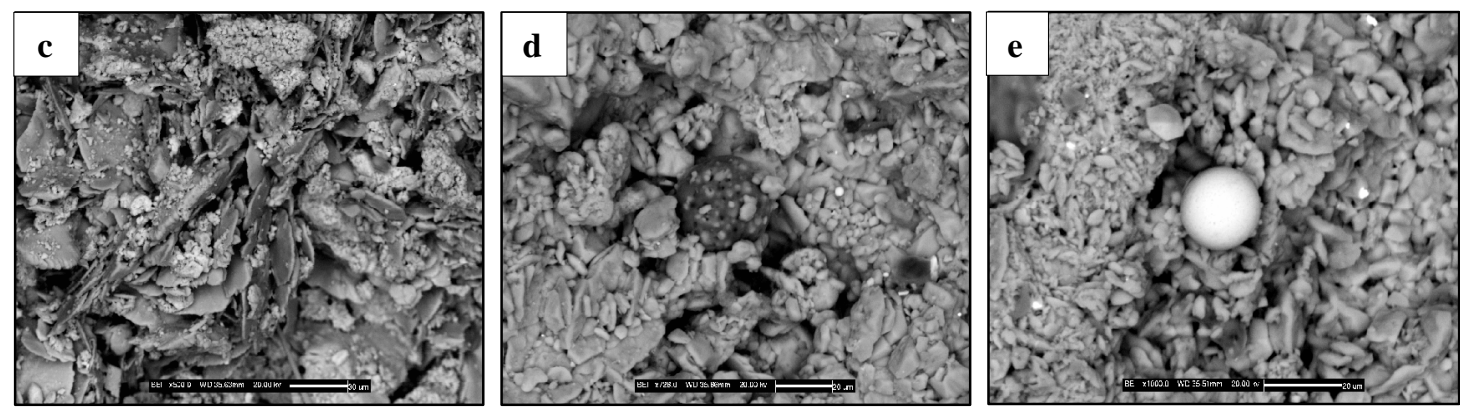

Figure (8) Shows $\underline{\mathbf{a} .}$ \& $\underline{\mathbf{b}}$. SEM-BSE image of surface of sample MFC3 (left) and related X-ray map distribution of sulphur (right picture), $\underline{\mathbf{c}}$. sets of platy crystals of gypsum, $\underline{\mathbf{d}}$. carbonaceous particle, e. smooth spherical metal particle.

\section{Conclusions}

On the basis of mineralogical, petrographic and chemical analyses it has been possible to identify the stone. The samples, although are characterised by different chromatic feature, can be petrographically classified as grainstone/packstone and show three compositional varieties. Furthermore, it was possible to determine the provenance of the lithotype used in the monument by comparison with a detailed petrographic investigation of quarry's area. This study is very important to any assessment of the present availability of the stone for replacement of decayed or missing parts of the ornamental material of the monument. The study of the decay products, their extent on the surface and in depth of the stone and the causes that have led to their formation allows an important evaluation of decay degree to plan the restoration work. Thermal analyses of decayed stone samples show a significant amount of gypsum which is ascribed to sulphation processes mostly active during last decades. SEM analyses (back scattered electrons-BSE images) of cross-sections of decayed scabs show a dendritic crust with thickness lying between $30 \mu \mathrm{m}$ and $1 \mathrm{~mm}$. Embedded in the irregular aggregates of needle-shaped gypsum crystals, porous carbonaceous particles were observed. Carbonaceous, spherical and porous particles are emitted by the combustion of heavy oils, while smooth spherical particles, mainly composed of iron and other metals, derived from the combustion of fossil fuels. SEM analyses (BSE images) of cross sections show extensive micro-cracks in the limestone, parallel to the stone/crust interface, completely filled with gypsum. These cracks, of a thickness ranging between 5 to 30 $\mu \mathrm{m}$, reach millimetric lengths and may generally extend to a depth of $5 \mathrm{~mm}$ inside the stone, even if sometimes they can develop at higher depth. The information acquired confirms the usefulness of this multi-problematic approach to the detailed evaluation of weathering phenomena to decide the most appropriate procedure of restoration to be carried out. Considering the general decrease in $\mathrm{SO}_{2}$ emissions in the last few years, it is presumed that, after proper restoration, the monument can be well conserved in time.

\section{Acknowledgements}

Authors are indebted with Prof. Lucia Baccelle Scudeler and Cristina Stefani for the petrographic mineralogic analyses. The author is also indebted to Prof. Dr. Mohammed A. ElGohary (Sohag Univ., Egypt) for having requested and stimulated this study.

\section{References}

[1] Cattaneo, A., De Vecchi, G. \&. Menegazzo Vitturi, L., (1976). Le pietre tenere dei colli Berici. Atti e Memorie dell'Accademia Patavina di Scienze, Lettere ed Arti, Vol. LXXXVIII, pp: 79-100.

[2] Fassina, V. \& Cherido, M., (1985). The Nanto stone deterioration and restoration of loggia Cornaro in Padova, in: Félix, G. (ed.) $V^{\text {th }}$ Int. Cong. on Deterioration and Conservation of stone, Polytechniques Romandes, Lausanne, pp: 313-324.

[3] Torraca, G., (1969). L'attuale stato delle conoscenze sulle alterazioni delle pietre. cause e metodi di trattamento, in: Gnudi, C. (ed.), Sculture all'Aperto, Degradazione dei Materiali e Problemi Conservativi, Rapporto della Soprintendenza alle Gallerie di Bologna, No.3, Edizioni Alfa, Bologna, pp: 9-30. 
[4] Marchesini, L., (1970). Effetti dell' inquinamento atmosferico sui materiali lapidei a Venezia, Aria e Acqua, Vol. III, 22, pp: 10-18

[5] Lazzarini, L., (1972). Forme e cause di alterazione di alcuni marmi $e$ pietre a Venezia, Centro di Studio Cause di Deperimento e metodi di Conservazione delle Opere d'arte, CNR, Roma, Pub. ${ }^{\circ}$ 21, 27 p.

[6] Lazzarini, L., (1979). Morfologia del degrado dei materiali lapidei a Venezia, in: Valcanover, F. (ed.) Atti del Convegno Associazione Civica Venezia Serenissima, Venezia, pp: 47-57.

[7] Fassina, V., Lazzarini, L. \& Biscontin, G., (1976). Effects of atmospheric pollutants on the composition of black crusts deposited on Venetian marbles and stones, in: Skoulikidis, $\mathrm{T}$. (ed.) $2^{\text {nd }}$ Int. Symp. on the Deterioration of Building Stones, Athens, pp: 201-211.

[8] Fassina, V., Favaro, M., Crivellari, F. \& Naccari, A., (2001). The stone decay of monuments in relation to atmospheric environment. Annali di Chimica, Vol. 91, pp: 767-774.

[9] Fassina, V., Favaro, M. \& Naccari, A., (2002), Principal decay patterns on Venetian monuments, in: Siegesmung, S., Weiss, T. \& Volbrecht A. (eds.) Natural Stone, Weathering Phenomena, Conservation Strategies and case studies, Geological Society, Special Pub., no. 205, pp: 381-391.

[10] Fassina, V., (1978). A survey on air pollution and deterioration of stonework in Venice, Atmospheric Environment, Vol. 12, pp: 2205- 2211.

[11] Fassina, V., (1988a). Stone decay of Venetian monuments in relation to air pollution, in: Marinos, P. \& Koukis, G. (eds.) Int. Symp. on the Engineering Geology of Ancient Work, Monuments and Historical Sites., A.A. Balkema, Rotterdam, pp: 787-796.

[12] Fassina, V., (1988b). The stone decay of the main Portal of Saint Mark's Basilica in relation to natural weathering agents and to air pollution, in: Ciabach, J. (ed.) VI ${ }^{\text {th }}$ Int. Cong. on Deterioration and Conservation of Stone, Nicholas Copernicus Univ, Torun pp: 276-286.

[13] Fassina, V., (1993). The weathering mechanisms of marble and stone of Venetian monuments in relation to the environment, in: ICOM (ed.) $10^{\text {th }}$ Triennial Meeting of ICOM, ICOM Committee for Conservation Washington, pp: 345-351.

[14] Fassina, V., (1994). The influence of atmospheric pollution and past treatments on stone weathering mechanisms of Venetian monuments, European Cultural Heritage Newsletter, Vol. 8 (2), pp: 23-35.

[15] Fassina, V. \& Stevan, A., (1992) Fogwater composition in Venice in relation to stone decay, in Rodrigues, D. (ed.) $7^{\text {th }}$ Int. Cong. on Deterioration and Conservation of Stone, Laboratório Nacional de Engenharia Civil, Lisbon, pp: 365-374.

[16] Camuffo, D., Del Monte, M. \& Sabbioni C., (1987). Influenza delle precipitazioni e della condensazione sul degrado superficiale dei monumenti in marmo e calcare, in: Ministero dei Beni Culturali ed Ambientali (ed.) Materiali lapidei, speciale issue del Bollettino d'Arte, pp: 15-36

[17] Amoroso, G. \& Fassina, V., (1983). Stone Decay and Conservation: Atmospheric pollution-cleaning-consolidation and Protection, Elsevier, Amsterdam.

[18] Various authors (2012), EN 16085, conservation of cultural propertymethodology for sampling from materials of cultural property - general rules, CEN TC 346, Bruxelles.

[19] Dunham, R., (1962), Classification of carbonate rocks according to depositional texture, in: Ham, W. (ed.) Classification of Carbonate Rocks, American Association of Petroleum Geologists Memoir 1, USA, pp: 108121.

[20] Embry, A. \& Klovan, J., (1971). A Late Devonian reef tract on North eastern Banks Island, N.W.T: Can- 
adian Petroleum Geology Bulletin, Vol. 19, pp: 730-781.

[21] Fassina, V., (1999). Analisi dei prodotti di alterazione delle superfici dei monumenti mediante cromatografia ionica, in: Cavalli, S. \& Sarzanini C., (eds.) La Cromatografia Ionica nell'Analisi Ambientale, pp: 201-220.

[22] Fassina, V., (1983). L'ossidazione dell' $\mathrm{SO}_{2}$ in atmosfera e la formazione delle croste sulle superfici lapidee, in: Angeli, F. Atti del Convegno "Le piogge acide", Milano, pp: 116-133.

[23] Fassina, V., (1987). Influenza dell' inquinamento atmosferico sui processi di degrado dei materiali lapidei, Bollettino d'Arte, Supl., No. 41, pp. 19-47.

[24] Fassina, V., (1988c). Environmental pollution in relation to stone decay, Durability of Building Materials, 5, pp. 317-368.

[25] Sabbioni, C., (1995). Contribution of atmospheric deposition to the formation of damage layers", STOTEN, 167, pp. 49-55.

[26] Camuffo, D., (1998). Microclimate for cultural heritage, Elsevier, Amsterdam.

[27] Johansson, L., Lindqvist, O. \& Mangio R., (1988). Corrosion of calcareous stones in humid air containing $\mathrm{SO}_{2}$ and $\mathrm{NO}_{2}$. Durability of Building Materials, Vol. 5, pp. 439-449.

[28] Sabbioni, C., Zappia, G., Ghedini, N. \& Gobbi, G., (1996). Carbon due to atmospheric deposition on stone monuments and historical buildings, in: Riederer, J. (ed.) $8^{\text {th }}$ Int. Cong. on Deterioration and Conservation of
Stone, Möller Druck und Verlag Berlin, pp: 333-337.

[29] Benchiarin, S., Baccelle Scudeler, L., Fassina, V., Molin, G. \& Stefani C., (2007). Survey of deterioration processes in a Renaissance monument, St. Anthony's Basilica, Padova, Italy, in: Zezza, F., Perthuisot, V. \& Plançon, A. (eds.) $7^{\text {th }}$ Int. Symp. On the Conservation of Monuments on the Mediterranean Basin, UNESCO, Orleans, pp. 45-53.

[30] Benchiarin, S., Fassina, V. \& Molin, G. (2008). New Facets on the Deterioration of Nanto Stone, in, Lukaszewicz, J. \& Niemcewicz, P. (eds.) $11^{\text {th }}$ Int. Cong. on Deterioration and Conservation of Stone, Uniwersytetu Mikołaja Kopernika, Torun, pp. 31-39.

[31] Fassina, V., Benchiarin, S. \& Molin, G. (2014). Assessment of funerary monuments stone decay in Saint Anthony Basilica in Padova, in: NTUA (ed.) $6^{\text {th }}$ Int. Cong. "Science and Technology for the Safeguard of Cultural Heritage in the Mediter-ranean Basin, Athens, Rome 2014, Vol III pp. 212-219.

[32] Fassina, V., Benchiarin, S. \& Molin, G. (2014). Condition survey on XIVXVIII century funerary monuments in the cloisters of St. Anthony Basilica in Padua, in Lollino, G., Giordan, D. Marunteanu C., Christaras B., Yoshinori I., Margottini C. (eds) Engineering Geology for Society and Territory, Springer, Vol. 8, pp.547-552. 